v. $10, n .4$

Vitória-ES, Out.-Dez. 2013

p. $110-132$ ISSN 1808-2386 DOI:http://dx.doi.org/10.15728/bbr.2013.10.4.5

\title{
The Effect of Brazilian convergence to IFRS on earnings managment by listed Brazilian nonfinancial companies ${ }^{\mathrm{i}}$
}

\author{
Marta Cristina Pelucio Grecco ${ }^{\dagger}$ \\ Mackenzie Presbyterian University
}

\begin{abstract}
This article evaluates whether the changes in Brazilian accounting practices due to the convergence to international standards brought a reduction in earnings management by listed nonfinancial firms, causing an improvement in the quality of accounting information. We used the Jones model, as modified by Kothari, Leone \& Wasley (2005), to measure earnings management by means of discretionary accruals using a sample of 361 companies between 2005 and 2011. The results indicate there was a change in earnings management through discretionary accruals after the convergence to IFRS in Brazil. We also found evidence that larger and more leveraged Brazilian firms tend to manage earnings less, but no evidence that being audited by one of the Big Four reduces the propensity for earnings management.
\end{abstract}

Keywords: Earnings management; IFRS; convergence; quality of accounting information; modified Jones model.

E-mail: marta.pelucio@praesum.com.br

Telephone: +55 11 99620-6708

Editor's Note: This article was accepted by Bruno Funchal and Fernando Caio Galdi 


\section{INTRODUCTION} information asymmetry between investors (principals) and managers (agents) (Jensen \& Meckling, 1976). The process of preparing the financial statements involves a series of estimates and judgments by managers in interpreting the firm's results, as well as the choice of the accounting practices to be adopted.

This process of choice and judgment by managers directly influences the book value of the company, as reflected in the accounting statements. While it is necessary for managers to make choices, the concern of investors is that this leeway for choice not be used opportunistically to manipulate the accounting results. The intentional manipulation of the results is called earnings management. It should be stressed that earnings management does not constitute fraud when the intentional alteration of numbers is done within the limits established by accounting standards (Martinez, 2001).

Many articles have been published on earnings management, especially in the past two decades (e.g., Jones, 1991; Dechow, Sloan \& Sweeney, 1995; Leuz, Nanda \& Wysocki, 2003; Kothari, Leone \& Wasley, 2005; Iatridis, 2012, to mention just a few).

Earnings management is restricted by accounting rules, in particular by those issued by capital market regulators, in the interest of assuring the quality and comparability of information and the transparency and unbiased disclosure of the firm's performance and equity position. Therefore, it is logical to expect that when there are changes in accounting standards so that they become stricter, this will cause an improvement in the quality of accounting information by reducing the room for manipulation of the results

In Brazil, as in many other countries, a significant change has occurred in the accounting rules due to the process of convergence to International Financial Reporting Standards (IFRS). This has motivated academics and market analysts to seek evidence of changes in the quality of accounting information due to this new framework.

Various studies have been published examining the effects of introduction of IFRS on earnings management (e.g., Aubert \& Grudnitski, 2012; Barth et al., 2012; Tsipouridou \& Spathis, 2012; Wang \& Campbell, 2012; Zéghal, Chtourou \& Sellami, 2011). However, few studies have been published on this topic in Brazil.

Therefore, the aim of this study is to evaluate whether the changes in Brazilian accounting practices brought be the recent convergence to international standards reduced the 
propensity of listed nonfinancial companies to manage their earnings, thus improving the quality of accounting information.

According to Lambert, Leuz \& Verrechia (2006, p. 29), a company's accounting decisions and disclosure system not only affect the decisions of investors and creditors, they also affect the actions of competitors, regulatory authorities and other actors.

With this study we intend to provide relevant information to market analysts and society as a whole about the quality of the information contained in accounting statements after the application of IFRS in Brazil, as well as to regulators on the efficiency of the rules limiting earnings management and academics for their research into the quality of accounting information and its reflections in the area of finance.

In the past decade there has been a sharp increase in foreign direct investments in emerging countries, chief among them the BRICS (Brazil, Russia, India, China and South Africa), justifying the importance of works seeking to measure the quality of the accounting information in these countries. In 2012, $20 \%$ of foreign investments were directed to the BRICS, and of this portion, 25\% went to Brazil (UNCTAD, 2013).

We applied the Jones model, as modified by Kothari, Leone \& Wasley (2005), to estimate the discretionary accruals with a sample of 361 Brazilian firms in the period from 2005 to 2011 . We then applied a model developed by us to detect the effect of implementation of IFRS in Brazil. Following Ghosh, Marra \& Moon (2010) and Jouber \& Fakhfakh (2012), among other authors, we used three control variables: auditor (Big Four or not), firm size and level of indebtedness.

\section{THEORETICAL FRAMEWORK AND DEVELOPMENT OF THE RESEARCH HYPOTHESES}

\subsection{THE ACCOUNTING PROCESS}

The objective of the financial statements, according to the Conceptual Framework of the International Accounting Standards Board (IASB), is "to provide information about the financial position, performance and changes in financial position of an entity that is useful to a wide range of users in making economic decisions" (IASCF, 2010, p. 80).

The process of preparing the financial statements in Brazil involves the recognition, measurement and disclosure of various elements (assets, liabilities, revenues and expenses) and has two basic premises: operational continuity and the accrual regime. However, the various ways of valuing assets and liabilities can result in different earnings values. 
The existence of accruals arises from the difference in the timing of the recognition of revenues and expenses between the accrual and cash accounting regimes. Therefore, the accounting result of a firm can be represented by Equation 1 (Rayburn, 1986).

$$
\mathrm{AE}=\mathrm{CF}+\mathrm{TA}
$$

Where:

$\mathrm{AE}=$ accounting earnings, under the accrual regime;

$\mathrm{CF}=$ cash flow generated by the firm (equal to the result by the cash regime);

$\mathrm{TA}=$ total accruals

\subsection{EARNINGS MANAGEMENT}

According to Degeorge, Patel \& Zeckhauser (1999) "executives have both the incentive and ability to manage earnings. It is hardly surprising that the popular press frequently describes companies as engaged in earnings management - sometimes referred to as manipulation."

The intentional manipulation of accounting information occurs when managers try to mislead investors (Watts \& Zimmerman, 1986). According to Christie \& Zimmerman (1994), managers' choices can be made efficiently, to maximize the real value of the company, or opportunistically, to obtain benefits for themselves to the detriment of investors.

Matsumoto \& Parreira (2007) identified that the main reasons for the continuing existence of earnings management are the inability of accounting rules to cover all possible situations and the existence of economic and financial incentives to engage in the practice.

Earnings management through accruals is directly connected to the difference between the cash and accrual regimes of accounting. As stated by Healy (1985), nondiscretionary accruals are those that are required by an accounting rule on the application of the accrual regime, such as the accounting of fixed assets and the systems for depreciation of assets. In turn, discretionary accruals refer to adjustments carried out intentionally by managers to adjust the bottom-line results.

Cupertino \& Martinez (2008) showed that the levels of accruals serve as a measure of manipulation of results, and consequently as an indication to orient auditors. Additionally, Almeida et al. (2009) demonstrated the possible existence of heterogeneous earnings management practices among firms in the same sector, suggesting analysis by strategic groups. 
There has been a substantial effort among academics to find empirical evidence of the relationship between earnings management practices and various factors, such as: corporate governance (e.g., Iatridis, 2012; Price, Roman \& Rountree, 2011; Chen, Kao \& Tsao, 2010); monitoring, shareholding structure and CEO and CFO rotation (e.g., Jouber \& Fakhfakh, 2012; Kang, Kilgore \& Wright, 2011; Ayers, Ramalingegowda \& Yeung, 2011; Hazarika, Karpoff \& Nahata, 2012); management structure and existence of an audit committee (e.g., Ghosh, Marra \& Moon, 2010); cost of equity and debt capital (e.g., Rodríguez-Pérez \& Van Hemmen, 2010; Coelho \& Lopes, 2007; Nardi et al.; 2009); tax planning (e.g., Formigoni, Antunes \& Paulo, 2009; Rezende \& Nakao, 2012); and audit firm identity (e.g., Martinez \& Reis, 2010; Silva \& Bezerra, 2010).

\subsection{INTERNATIONAL AND BRAZILIAN ACCOUNTING PRACTICES}

A good deal of effort has been directed to establishing uniform international accounting standards, specifically through the issuance of the International Financial Reporting Standards (IFRS), which were adopted starting in 2005 in the European Union, applicable to all firms with securities traded on bourses in that jurisdiction.

Among the advantages of the adoption of uniform accounting practices, according to Martins \& Brasil (2008), is to raise the quality of the information disclosed due to the greater transparency and comparability, reducing the risk of investments and the cost of capital.

Studies of the implementation of IFRS in Europe through the application of earnings management models have generally shown a reduction in this management (e.g., Aubert \& Grudnitski, 2012; Barth et al., 2012; Leventis, Dimitropoulos \& Anandarajan, 2011; Zéghal, Chtourou \& Sellami, 2011) or neutrality (e.g., Fernandes, 2011; Wang \& Campbell, 2012, Jeanjean \& Stolowy, 2008). Other studies have indicated that firms in countries with common law legal systems tend to manipulate earnings less than do those located in code law countries, even after IFRS implementation (e.g., Jeanjean \& Stolowy, 2008; Shelton, OwensJackson \& Robinson, 2011).

In light of the recent convergence to IFRS in Brazil and considering the evidence already found of the effect of this convergence on earnings management, we formulated the following first research hypothesis - Hypothesis 1: There is a decrease in earnings management in the financial statements elaborated below the light of IFRS when compared to the Brazilian valid accounting practices before the transition time's beginning (until 2007), as found in other countries (Aubert \& Grudnitski, 2012; Barth et al, 2012; Leventis, Dimitropoulos \& Anandarajan, 2011; Zéghal, Chtourou \& Sellami, 2011). 


\subsubsection{Brazilian Convergence to IFRS}

A committee was created in Brazil in 2005 to issue accounting standards in harmony with IFRS: the Accounting Pronouncements Committee (Comitê de Pronunciamentos Contábeis, or CPC). Additionally, all listed companies, including financial institutions, have since 2010 been required to present their accounting statements according to IFRS, respectively according to the rules issued by the Brazilian Securities Commission (CVM) and Central Bank of Brazil.

The process of convergence to IFRS in Brazil was divided into two steps. The first was composed of the alterations to the Law of Corporations (Law 6,404/76) brought by Law $11,638 / 07$ and the documents issued by the CPC, valid starting in 2008. The second step began in 2010 and was introduced by pronouncements issued by the CPC, valid starting in 2010 but with comparative effect for 2009 (requiring firms to republish their financial statements for 2009 in 2010 according to the new standards).

Therefore, three different periods can be identified regarding IFRS in Brazil: the preIFRS period, under the old practices, up through 2007; the hybrid period, with partially convergent accounting practices, covering 2008 and 2009; and the full-IFRS period, after complete adoption of the international standards, from 2010 onward (with republication of the financial statements that year for 2009 , for purposes of comparison).

The adoption of IFRS brought a series of changes in the criteria for recognition, measurement and accounting of assets, liabilities, revenues and expenses.

Alves Oliveira \& Lemes (2011) analyzed the financial statements of Brazilian firms in the hybrid period (specifically 2008) to assess the level of conformity to IFRS of the information disclosed to the Brazilian and American markets. They detected a greater level of convergence between USGAAP and IFRS than between BRGAAP and IFRS, suggesting that Brazilian accounting statements that year tended to change substantially, increasing the level of disclosure.

Barbosa Neto, Dias \& Pinheiro (2009) performed a comparative analysis of financial ratios between the pre-IFRS and hybrid periods and found that these were not affected in a statistically significant manner. In contrast, in a similar study Martins \& Paulo (2010) observed that partial IFRS adoption in the hybrid period reduced the discrepancies between the ratios calculated according to Brazilian and international practices. 
Zonatto et al. (2011), in an analysis of companies in the electric power sector (under government and private control), found that size, financing need, total debt, fixed assets and return on equity were the factors that best explained the adherence to international accounting standards by the firms in the sample.

In a process of gradual alteration of accounting practices as happened in Brazil, divided into two distinct steps, it is reasonable to expect a gradual improvement in the quality of accounting information, leading to our second hypothesis - Hypothesis 2: There was a reduction of earnings management in the financial statements prepared in the hybrid period in relation to those in the pre-IFRS period (up through 2007).

\section{METHODOLOGICAL PROCEDURES}

The population of this study is composed of listed Brazilian companies and the sample is non-probabilistic, formed of all nonfinancial firms with securities listed for trading on the São Paulo Stock, Mercantile and Futures Exchange (BM\&FBovespa) on October 2, 12 (361 firms) with data available for the entire study period, from 2005 to 2011.

The data were collected from the CVM's website as follows: the data from the pre-IFRS period were obtained from the financial statements for 2007 and from the comparative figures presented that year for 2005 and 2006; the data from the hybrid period were taken from the accounting statements for 2009 and the comparative figures published that year for 2008; and the data for the full-IFRS period were taken from the financial statements for 2011, with use of the figures for 2010 presented for comparative purposes.

\subsection{EMPIRICAL MODELS TO DETERMINE THE EXISTENCE OF EARNINGS MANAGMENT BY DISCRETIONARY ACCRUALS}

As seen, accruals exist because of the adjustment between the cash and accrual accounting regimes (see Equation 1). To verify whether there was manipulation of results by means of accruals, it is necessary to divide accruals into those that are normal (nondiscretionary) and those that are abnormal (discretionary).

Discretionary accruals are not directly observable. The only way to estimate them is by the difference between total accruals and nondiscretionary accruals. Therefore, the first step to estimate discretionary accruals is to estimate the firm's total accruals.

Total accruals can be obtained directly by the difference between earnings and operating cash flow reported in the accounting statements (De Angelo, 1986, p. 410). When information on operating cash flow is not available, a model must be applied to estimate the total accruals. 
In Brazil it was not necessary until 2007 to present a cash flow statement, so we estimated the total accruals.

The total accruals can be estimated with data from the balance sheet and income statement, according to Equation 2 (Jones, 1991, p. 211; Dechow, Sloan \& Sweeney, 1995, p. 203).

$\mathrm{TA}_{\mathrm{t}}=\frac{\left(\Delta C A_{\mathrm{t}}-\Delta C a s h_{\mathrm{t}}\right)-\left(\Delta C L_{\mathrm{t}}-\Delta S T D_{\mathrm{t}}\right)-D e p_{\mathrm{t}}}{A_{\mathrm{t}-1}}$

Where:

$T A_{t}=$ total accruals of the firm in period $\mathrm{t}$;

$\Delta C A_{t}=$ variation of current assets from the end of period $\mathrm{t}-1$ to the end of period $\mathrm{t}$;

$\Delta \operatorname{Cash}_{t}=$ variation of cash and cash equivalents from the end of period $\mathrm{t}-1$ to the end of period t;

$\Delta C L_{t}=$ variation of current liabilities from the end of period $\mathrm{t}-1$ to the end of period $\mathrm{t}$; $\triangle S T D_{t}=$ variation of short-term debt from the end of period $\mathrm{t}-1$ to the end of period $\mathrm{t}$;

Dep $p_{t}=$ amount of depreciation and amortization expense during period $\mathrm{t}$;

$A_{t-1}=$ total assets at the end of period $\mathrm{t}-1$.

\subsubsection{Models to Estimate Discretionary Accruals}

In studies that analyze discretionary accruals, after observing or estimating the total accruals, the next step is to estimate the amount of these accruals that are normal (nondiscretionary) and abnormal (discretionary). According to Healy (1985), nondiscretionary accruals (NDA) reflect the average of the firm's total accruals in the period studied. DeAngelo (1986) estimated the variations of NDA in function of the variations of total accruals between the previous period and period of interest by using the average as described by Healy (1985).

As observed by Jones (1991) and Dechow, Sloan \& Sweeney (1995), these models only do not produce errors if the NDA are constant in time. Otherwise, there will be defects in the estimation. Therefore, Jones (1991) proposed a more flexible model (Jones model, or JM) with respect to the variations in NDA in time, measuring them in function of revenues and fixed assets (property, plant and equipment). 
Dechow, Sloan \& Sweeney (1995) observed that the JM considers that revenue cannot be manipulated, which is not always the case, so this also should be considered as a discretionary element. Dechow, Sloan \& Sweeney (1995) thus proposed an alteration of the $\mathrm{JM}$, which is customarily called the modified Jones model in the literature, including the variation of accounts receivable $\left(\triangle R E C_{t}\right)$ in the formula.

Kothari, Leone \& Wasley (2005), based on the observations of Dechow, Sloan \& Sweeney (1995), pointed out that the modified Jones model is susceptible to presenting higher discretionary accruals (DA) when firms are growing. Therefore, they presented another modification of the JM, according to Equation 3, including return on assets (ROA).

$$
\frac{T A_{i t}}{A_{i t-1}}=\alpha\left(\frac{1}{A_{i t-1}}\right)+\beta_{1}\left[\frac{\left(\Delta R E V_{i t}-\Delta R E C_{i t}\right)}{A_{i t-1}}\right]+\beta_{2}\left(P P E_{i t} / A_{i t-1}\right)+\beta_{3}\left(R O A_{i t}\right)+\epsilon_{i t}
$$

Where:

$T A_{i t}=$ total accruals of firm $\mathrm{i}$ in period $\mathrm{t}$;

$\triangle R E V_{i t}=$ revenues in period $\mathrm{t}$ minus revenues in period $\mathrm{t}-1$ of firm $\mathrm{i}$;

$\triangle R E C_{i t}=$ accounts receivable in period $\mathrm{t}$ minus accounts receivable in period $\mathrm{t}-1$ of firm i;

$P P E_{i t}=$ property, plant and equipment of firm $\mathrm{i}$ in period $\mathrm{t}$;

$R O A_{i t}=$ return on assets (net income divided by total assets) of firm i in period $\mathrm{t}$;

$A_{i t-1}=$ total assets of firm $\mathrm{i}$ in period $\mathrm{t}-1$;

$E_{i t}=$ regression error of firm $\mathrm{i}$ in period $\mathrm{t}$ (measurement of the DA).

The use of the JM and its variations is widespread in the international literature, the main ones being the modification proposed by Dechow, Sloan \& Sweeney (1995) with the inclusion of receivables, and the further modification suggested by Kothari, Leone \& Wasley (2005), with the inclusion also of return on assets. Table 1 lists some of the studies found between the years 2009 and 2012 in international periodicals using the referred models. 
Table 1: Studies published in international periodicals using the Jones model and its variations between 2009 and 2012

\begin{tabular}{|c|c|c|}
\hline Jones (1991) & Dechow, Sloan \& Sweeney (1995) & Kothari, Leone \& Wasley (2005) \\
\hline Baxter \& Cotter (2009) & Ahn \& Choi (2009) & $\begin{array}{l}\text { Bona - Sánchez, Pérez - Alemán \& } \\
\text { Santana - Martín (2011) }\end{array}$ \\
\hline Chan et al (2010) & Ayers, Ramalingegowda \& Yeung (2011) & Cheng, Aerts \& Jorissen (2010) \\
\hline $\begin{array}{l}\text { Cohen \& Zarowin } \\
(2010)\end{array}$ & Chen, Kao \& Tsao (2010) & Choi \& Pae (2011) \\
\hline Iatridis (2012) & Chen, Liao \& Lu (2012) & Cohen \& Zarowin (2010) \\
\hline Nguyen \& Xu (2010) & Chi \& Grupta (2009) & Ettredge et al (2010) \\
\hline \multirow[t]{12}{*}{ Niskanen et al. (2011) } & Chung, Sheu \& Wang (2009) & Guthrie \& Sokolowsky (2010) \\
\hline & Gargouri, Shabou \& Francoeur (2010) & Hazarika, Karpoff \& Nahata (2012) \\
\hline & Ghosh, Marra \& Moon (2010) & Ibrahim (2009) \\
\hline & Hadani, Goranova \& Khan (2011) & Jaggi, Leung \& Gul (2009) \\
\hline & Hutton, Marcus \& Tehranian (2009) & Jouber \& Fakhfakh (2012) \\
\hline & Jiang, Petroni \& Wang (2010) & Kang, Kilgore \& Wright (2011) \\
\hline & Jorion, Shi \& Zhang (2009) & Lee \& Masulis (2011) \\
\hline & Kang, Kilgore \& Wright (2011) & $\begin{array}{l}\text { Rodríguez-Pérez \& van Hemmen } \\
(2010)\end{array}$ \\
\hline & Kim \& Yi (2009) & Sun, Liu \& Lan (2011) \\
\hline & $\begin{array}{l}\text { Labelle, Makni Gargouri \& Francoeur } \\
\text { (2010) }\end{array}$ & Wilson \& Wang (2010) \\
\hline & McInnis \& Collins (2011) & Wilson \& Wu (2011) \\
\hline & Wang \& Yung (2011) & \\
\hline
\end{tabular}

Kang \& Sivaramakrishnan (1995) developed another model to detect earnings management, known in the academic literature as the KS model, represented by Equation 4.

$$
\frac{T A_{\text {it }}}{A_{\text {it }-1}}=\alpha+\beta_{1}\left(\delta_{1} \frac{R E V_{\text {it }}}{A_{\text {it }-1}}\right)+\beta_{2}\left(\delta_{2} \frac{E X P_{i t}}{A_{\text {it }-1}}\right)+\beta_{3}\left(\delta_{3} \frac{G P P E_{\text {it }}}{A_{\text {it }-1}}\right)+\epsilon_{\text {it }}
$$

Where:

$$
\begin{aligned}
& \delta_{1}=R E C_{i t-1} / R E V_{i t-1} ; \\
& \delta_{2}=\left(I N V_{i t-1}+O C A_{i t-1}-C L_{i t-1}\right) / E X P_{i t-1}
\end{aligned}
$$

$I N V_{i t-1}=$ balance of inventories of firm $\mathrm{i}$ in period $\mathrm{t}-1$;

$O C A_{i t-1}=$ other current assets (prepaid expenses) of firm $\mathrm{i}$ in period $\mathrm{t}-1$;

$C L_{i t-1}=$ balance of accounts payable in the current liabilities of firm $\mathrm{i}$ in period $\mathrm{t}-1$;

$E X P_{i t}=$ expenses of firm $\mathrm{i}$ in period $\mathrm{t}$, excluding expenses for depreciation and amortization at the end of period $\mathrm{t}-1$;

$$
\delta_{3}=D E P_{i, t-1} / G P P E_{i, t-1}
$$


$D E P_{\text {it }-1}=$ amount of expenses from depreciation and amortization of firm $\mathrm{i}$ in period $\mathrm{t}-1$

$$
\begin{aligned}
& G P P E_{i t-1}=\text { balance of gross property, plant and equipment of firm i in period } \mathrm{t}-1 \text {; } \\
& \alpha_{3} \beta_{1}, \beta_{2}, \beta_{3}=\text { estimated coefficients of the regression; } \\
& \epsilon_{i t}=\text { regression error. }
\end{aligned}
$$

According to Martinez (2001, p. 48) "a perfect model does not exist, but within the current state of the art the KS model appears to provide the best results."

We did not find any studies using the KS model in the international literature. Brazilian studies of earnings management for the most part investigate the topic by means of discretionary accruals, with the use of the Jones model and its modifications and the KS model, as shown in Table 2.

Table 2: Brazilian studies using discretionary accruals

\begin{tabular}{l|l|l}
\hline \multicolumn{1}{c|}{ Jones (1991) } & \multicolumn{1}{|c}{ Dechow, Sloan \& Sweeney (1995) } & Kang \& Sivaramakrishnan (1995) \\
\hline Cupertino \& Martinez (2008) & Coelho \& Lopes (2007) & Paulo, Martins \& Corrar (2007) \\
\hline Vasconcelos et al. (2008) & Paulo, Martins \& Corrar (2007) & Martinez (2008) \\
\hline & Cupertino \& Martinez (2008) & Vasconcelos et al. (2008) \\
\hline & Almeida et al. (2009) & Almeida \& Almeida (2009) \\
\hline & Nardi et al. (2009) & Almeida et al. (2009) \\
\hline & Paulo \& Leme (2009) & Martinez (2009) \\
\hline & & Nardi \& Nakao (2009) \\
\hline & & Nardi et al. (2009) \\
\hline & & Paulo \& Leme (2009) \\
\hline & & Silva \& Bezerra (2010) \\
\hline & & Martinez (2011) \\
\hline
\end{tabular}

To measure earnings management by means of discretionary accruals in this study, we apply the Jones model as modified by Kothari, Leone \& Wasley (2005) (MJM), whose modification is in harmony with the economic characteristic of Brazil as an emerging country, since it takes into consideration firms' growth, and the KS model.

\subsection{MODEL TO DETECT THE EFFECT OF IFRS ON EARNINGS MANAGEMENT}

To analyze the effect of adoption of IFRS on earnings management, we use as the dependent variable the absolute value of the estimated DA, which according to Jouber \& Fakhfakh (2012) measures the transfer from one period to another without being sensitive to whether the earnings increased or decreased. 
To verify whether there was a change in earnings management after the implementation of IFRS in Brazil, we use independent dummy variables to indicate the presence of the influence of IFRS on the preparation of the financial statements in the hybrid period (HYB) and full-IFRS period (IFRS). According to our hypotheses, we expect the signs of the coefficients of the variables IFRS and HYB to be negative, since the expectation is of a reduction of earnings management in the presence of the international accounting rules.

As indicated by previous empirical evidence, various factors can be related to earnings management or the restriction of this practice. Therefore, in the model applied to detect the effect of IFRS on earnings management, we also include some independent variables based on the evidence reported, as described below.

Following Ghosh, Marra \& Moon (2010) and Jouber \& Fakhfakh (2012), we include an independent dummy variable to indicate whether the firm was audited by one of the Big Four (AUDIT), because as found by the above authors, firms that are audited by one of the Big Four tend to manage earnings less than other firms. On the other hand, Martinez \& Reis (2010) and Silva \& Bezerra (2010) did not find evidence of a restrictive influence on earnings management by the audit firm. So, since the evidence in this respect is not conclusive, we make no prediction about the sign of the variable AUDIT.

According to Rodríguez-Pérez \& Van Hemmen (2010) and Nardi et al. (2009), increases in indebtedness produce incentives for managers to manipulate the results, so we include an independent variable of the debt level, or leverage (LEV). We expect the sign of this variable to be positive.

We additionally include firm size (SIZE) as a control variable, in line with Ghosh, Marra \& Moon (2010) and Jouber \& Fakhfakh (2012), among other authors, without any prediction of the sign of the coefficient.

Therefore, to identify the relationship between the adoption of IFRS on earnings management in Brazil, we apply Equation 5, in which besides the mentioned dummy variables, we include the effects of the interaction between the dummy variables IFRS and AUDIT.

$$
\begin{aligned}
& \left|D A_{i t}\right|= \\
& \alpha+\beta_{1} I F R S_{i t}+\beta_{2} H_{I B}+\beta_{3} A U D I T_{i t}+\beta_{4} I F R S_{i t} x A U D I T_{i t}+\beta_{5} H I B_{i t} x A U D I T_{i t}+ \\
& S_{I Z E_{i t}}+L E V_{i t}+\epsilon_{i t}
\end{aligned}
$$


Where:

$I F R S_{i t}=$ independent variable, with a value of 1 if the financial statements of firm $\mathrm{i}$ were prepared according to IFRS in year t, and 0 otherwise;

$H I B_{i t}=$ independent variable, with the value 1 if the financial statements of firm $\mathrm{i}$ were prepared according to the rules in the hybrid period in year t, and 0 otherwise;

$A U D I T_{i t}=$ independent variable, with the value 1 if firm $\mathrm{i}$ was audited by one of the Big Four in year $\mathrm{t}$, and 0 otherwise;

$S I Z E_{i t}=$ size of firm i in year $\mathrm{t}$, measured as the natural logarithm of total assets;

$L E V_{i t}=$ leverage of firm $\mathrm{i}$ in year $\mathrm{t}$, measured by the ratio of total liabilities (current and long-term) divided by the total assets.

\section{ANALYSIS OF THE RESULTS}

To estimate the discretionary accruals, we used cross-sectional analysis because it is most suitable of this purpose, as observed by Chen, Liao \& Lu (2012).

The main general statistics of the regression obtained in the application to estimate the discretionary accruals (Equations 3 and 4) are described in Table 3. 
Table 3 - Results of the Models Used to Estimate Discretionary Accruals

\begin{tabular}{|c|c|c|c|c|c|c|c|c|c|c|c|c|c|c|}
\hline \multirow[b]{3}{*}{ Independent Variable } & \multicolumn{4}{|c|}{ IFRS Period } & \multicolumn{4}{|c|}{ Hybrid Period } & \multicolumn{6}{|c|}{ Pre-IFRS Period } \\
\hline & \multicolumn{2}{|l|}{2011} & \multicolumn{2}{|l|}{2010} & \multicolumn{2}{|l|}{2009} & \multicolumn{2}{|l|}{2008} & \multicolumn{2}{|l|}{2007} & \multicolumn{2}{|l|}{2006} & \multicolumn{2}{|l|}{2005} \\
\hline & Coefficient & Prob. & Coefficient & Prob. & Coefficient & Prob. & Coefficient & Prob. & Coefficient & Prob. & Coefficient & Prob. & Coefficient & Prob. \\
\hline \multicolumn{15}{|l|}{ Modified Jones Model } \\
\hline ROA3* & 0.000 & 0.369 & -0.065 & 0.000 & 0.000 & 0.611 & \begin{tabular}{l|l|}
-0.002 \\
\end{tabular} & 0.000 & -0.020 & 0.014 & 0.004 & 0.000 & 2.543 & 0.324 \\
\hline $\mathrm{ROA} 2 *$ & 0.010 & 0.374 & -0.112 & 0.000 & 0.021 & 0.140 & -0.076 & 0.000 & -0.385 & 0.025 & 0.075 & 0.000 & 21.141 & 0.327 \\
\hline ROA & 0.129 & 0.104 & 0.236 & 0.108 & 0.676 & 0.002 & -0.015 & 0.888 & -1030562 & 0.187 & 0.412 & 0.000 & 8.871 & 0.515 \\
\hline REC3 * & -0.005 & 0.913 & -0.001 & 0.034 & -0.191 & 0.083 & -0.002 & 0.180 & 0.060 & 0.052 & 0.405 & 0.000 & -2.484 & 0.135 \\
\hline $\mathrm{REC} 2 *$ & 0.039 & 0.695 & 0.092 & 0.011 & -0.163 & 0.299 & 0.040 & 0.000 & -0.336 & 0.092 & \begin{tabular}{|l|}
-0.032 \\
\end{tabular} & 0.801 & 8.317 & 0.200 \\
\hline REC & 0.090 & 0.302 & \begin{tabular}{l|l|}
-0.070 \\
\end{tabular} & 0.394 & 0.037 & 0.786 & 0.043 & 0.375 & -0.386 & 0.131 & -0.576 & 0.000 & -10.017 & 0.257 \\
\hline PPE3 * & -0.024 & 0.593 & -0.004 & 0.166 & 0.153 & 0.086 & -0.108 & 0.000 & -0.114 & 0.000 & 0.000 & 0.954 & 66.482 & 0.096 \\
\hline PPE2 * & 0.066 & 0.675 & 0.118 & 0.159 & -0.474 & 0.118 & 0.554 & 0.000 & 0.660 & 0.000 & 0.018 & 0.915 & -111.605 & 0.097 \\
\hline PPE & -0.104 & 0.326 & -0.206 & 0.086 & 0.223 & 0.281 & -0.548 & 0.000 & -0.896 & 0.000 & -0.134 & 0.451 & 53.212 & 0.100 \\
\hline $\mathrm{A} 3$ & 23982214 & 0.000 & -3288523 & 0.896 & -624000000 & 0.128 & -37682845 & 0.266 & -925000000 & 0.174 & 48261107 & 0.002 & 8687201 & 0.159 \\
\hline $\mathrm{A} 2$ & -783938 & 0.000 & 17699 & 0.953 & 2850565 & 0.113 & 653450 & 0.179 & 6716264 & 0.150 & -487702 & 0.006 & -8757334 & 0.159 \\
\hline $\mathrm{A}$ & 1680 & 0.000 & 117.029 & 0.864 & -2821 & 0.102 & -1790 & 0.017 & -967 & 0.133 & 710 & 0.055 & 70164 & 0.185 \\
\hline $\mathrm{C}$ & -0.014 & 0.299 & 0.055 & 0.251 & -0.025 & 0.423 & 0.086 & 0.006 & 0.433 & 0.000 & 0.103 & 0.023 & -4.372 & 0.094 \\
\hline Number of firms & \multicolumn{2}{|l|}{350} & \multicolumn{2}{|l|}{296} & \multicolumn{2}{|l|}{327} & \multicolumn{2}{|l|}{314} & \multicolumn{2}{|l|}{298} & \multicolumn{2}{|l|}{281} & \multicolumn{2}{|l|}{283} \\
\hline Number of observ. & \multicolumn{2}{|l|}{4200} & \multicolumn{2}{|l|}{3552} & \multicolumn{2}{|l|}{3924} & \multicolumn{2}{|l|}{3768} & \multicolumn{2}{|l|}{3576} & \multicolumn{2}{|l|}{3372} & 3396 & \\
\hline Adjusted $\mathrm{R}^{2}$ & 0.364562 & & 0.997848 & & 0.563496 & & 0.889018 & & 0.580786 & & 0.999939 & & 0.483273 & \\
\hline F-statistic & 17.68560 & & 11400.81 & & 36.07022 & & 209.9393 & & 35.28904 & & 382417.7 & & 22.97855 & \\
\hline p-value & 0.0000000 & & 0.0000000 & & 0.0000000 & & 0.0000000 & & 0.0000000 & & 0.0000000 & & 0.0000000 & \\
\hline Durbin-Watson stat & 2.035270 & & 1.977233 & & 2.208356 & & 1.962676 & & 1.843852 & & 1.981761 & & 2.012572 & \\
\hline KS model $* *$ & & & & & & & & & & & & & & \\
\hline$\delta_{1}(\mathrm{REV})_{\mathrm{i}}$ & 0.000 & 0.000 & 231.739 & 0.337 & 654.583 & 0.419 & -1256 & 0.315 & 136431 & 0.328 & -37326 & 0.324 & & \\
\hline$\delta_{2}(\mathrm{EXP})_{\mathrm{i}}$ & 0.000 & 0.786 & -1.102 & 0.312 & -23.319 & 0.358 & 0.847 & 0.296 & -0.596 & 0.318 & 38.580 & 0.321 & & \\
\hline$\delta_{3}(\mathrm{GPPE})_{\mathrm{i}}$ & -0.789 & 0.056 & 873 & 0.329 & 12634 & 0.341 & -776 & 0.365 & 34.745 & 0.332 & -142384 & 0.346 & & \\
\hline $\mathrm{C}$ & -0.015 & 0.281 & \begin{tabular}{ll|}
-66.340 \\
\end{tabular} & 0.327 & -613 & 0.337 & 301 & 0.308 & -2728 & 0.318 & 9740 & 0.320 & & \\
\hline Number of firms & 350 & & 297 & & 329 & & 318 & & 300 & & 283 & & & \\
\hline Number of observ. & 1050 & & 891 & & 987 & & 954 & & 900 & & 849 & & & \\
\hline Adjusted $\mathrm{R}^{2}$ & -0.004136 & & -0.006398 & & -0.008053 & & -0.005364 & & -0.009497 & & -0.006755 & & & \\
\hline F-statistic & 0.52081 & & 0.372721 & & 0.12654 & & 0.4362 & & 0.06240 & & 0.369289 & & & \\
\hline p-value & 0.66823 & & 0.7727460 & & 0.9443450 & & 0.7272340 & & 0.9795900 & & 0.7752280 & & & \\
\hline Durbin-Watson stat & 2.03058 & & 1.99971 & & 2.00895 & & 2.01120 & & 2.00810 & & 2.00942 & & & \\
\hline
\end{tabular}

BBR, Braz. Bus. Rev. (Engl. ed., Online), 
We used the Eviews software to process the data, with estimation of the coefficient by least squares and White correction for heteroscedasticity, as suggested by Gujarati \& Porter (2008, p. 414).

From the F-statistics and p-values in Table 3, it can be seen that the modified Jones model is statistically significant at the usual confidence interval levels, while the KS model is not. Also, according to the adjusted $\mathrm{R}^{2}$ values, the MJM has strong explanatory power, while the KS model does not.

Therefore, we used the absolute values of the residuals, per firm and per period, obtained from Equation 3 based on the MJM, as the dependent variable in applying Equation 5 , because it has better explanatory power than the KS model,.

According to the tests carried out with Equation 5, the model with fixed effects is better adjusted to the composition of the data (F-test to detect fixed effects and Hausman specification test). The results of the model of the impact of IFRS on earnings management are reported in Table 4.

Table 4 - Results of the Model for the Impact of IFRS on Earnings Management

\begin{tabular}{|c|c|c|c|c|c|c|c|c|c|}
\hline \multirow{2}{*}{$\begin{array}{l}\text { Independent } \\
\text { Variable }\end{array}$} & \multirow{2}{*}{$\begin{array}{l}\text { Expected } \\
\text { Sign }\end{array}$} & \multicolumn{2}{|c|}{ (1) } & \multicolumn{2}{|c|}{ (2) } & \multicolumn{2}{|c|}{ (3) } & \multicolumn{2}{|c|}{ (4) } \\
\hline & & Coeffic. & Prob. & Coeffic. & Prob. & Coeffic. & Prob. & Coeffic. & Prob. \\
\hline IFRS & - & 0.727 & 0.957 & & & 0.539 & 0.983 & & \\
\hline HYB & - & 0.856 & 0.977 & & & 0.281 & 0.985 & & \\
\hline AUDIT & $?$ & 0.073 & 0.920 & & & 0.103 & 0.888 & & \\
\hline AUDIT x HYB & $?$ & 1.122 & 0.086 & 1.148 & 0.055 & 1.048 & 0.109 & 1.084 & 0.070 \\
\hline AUDIT x IFRS & $?$ & 1.374 & 0.061 & 1.402 & 0.038 & 1.239 & 0.090 & 1.278 & 0.058 \\
\hline LEV & + & -0.033 & 0.007 & -0.033 & 0.007 & -0.172 & 0.000 & -0.172 & 0.000 \\
\hline SIZE & $?$ & -0.890 & 0.000 & -0.890 & 0.000 & -2.648 & 0.000 & -2.647 & 0.000 \\
\hline LEV2 * & + & & & & & 0.000 & 0.000 & 0.000 & 0.000 \\
\hline SIZE2 * & $?$ & & & & & 0.073 & 0.012 & 0.072 & 0.012 \\
\hline Constant & NA & 11.978 & 0.311 & 12.490 & 0.000 & 22.508 & 0.069 & 22.797 & 0.000 \\
\hline \multicolumn{2}{|c|}{ Adjusted $\mathrm{R}^{2}$} & \multicolumn{2}{|c|}{0.039505} & \multicolumn{2}{|c|}{0.041109} & \multicolumn{2}{|c|}{0.047559} & \multicolumn{2}{|c|}{0.049161} \\
\hline \multicolumn{2}{|c|}{ F-statistic } & \multicolumn{2}{|c|}{1.242045} & \multicolumn{2}{|c|}{1.254385} & \multicolumn{2}{|c|}{1.292255} & \multicolumn{2}{|c|}{1.305105} \\
\hline \multicolumn{2}{|c|}{ p-value } & \multicolumn{2}{|c|}{0.002994} & \multicolumn{2}{|c|}{0.002071} & \multicolumn{2}{|c|}{0.00541} & \multicolumn{2}{|c|}{0.000354} \\
\hline \multicolumn{2}{|c|}{ Durbin-Watson stat. } & \multicolumn{2}{|c|}{1.447768} & \multicolumn{2}{|c|}{1.447731} & \multicolumn{2}{|c|}{1.428418} & \multicolumn{2}{|c|}{1.428307} \\
\hline
\end{tabular}

(1) Model of Equation 5 with fixed effects

(2) Model of Equation 5 with fixed effects, removing the variables without statistical significance

(3) Model of Equation 5 with fixed effects, with second degree polynomials

(4) Model of Equation 5 with fixed effects, with second degree polynomials, removing the variables without statistical significance

* We used second degree polynomials, as suggested by Gujarati \& Porter (2008, pp. 225-226).

As shown in Table 4, the p-values near zero indicate that the independent variables utilized (set of accounting rules in effect, Big Four auditor, firm size and leverage) all have the capacity to explain the behavior of the dependent variable (earnings management through discretionary accruals). 
In turn, the dummy variables, inserted to identify the influence of the rules in effect in the full-IFRS and hybrid periods, as well as to identify the effect of engaging one of the Big Four auditors, are not statistically significant individually. When analyzing the variables representing the interaction of accounting rules and Big Four engagement, the positive coefficient indicates an increase in earnings management in the full-IFRS period. However, this result is only statistically significant at the $10 \%$ level.

Finally, the firm size and debt level are inversely proportional to the absolute value of discretionary accruals at the usual confidence interval levels, with negative coefficients of the variables in question.

\section{FINAL CONSIDERATIONS}

We did not find evidence from the models applied here that the convergence to IFRS in Brazil had a restrictive effect on earnings management in either of the periods studied (fullIFRS or hybrid). This same finding has been reported by some other authors (Fernandes, 2011; Wang \& Campbell, 2012, Jeanjean \& Stolowy, 2008). Therefore, we conclude that unlike expected, there is no evidence of an increase in the quality of accounting information in Brazil in the IFRS era when considering earnings management by use of discretionary accruals.

We also did not find evidence that being audited by one of the Big Four tends to reduce earnings management in Brazil, as also confirmed by Martinez \& Reis (2010) and Silva \& Bezerra (2010).

The results of analyzing the effects of the accounting rule periods (full-IFRS and hybrid) with interaction of Big Four auditing suggest an increase in earnings management after Brazilian convergence to IFRS, both partial in the hybrid period and complete in the fullIFRS period, only of firms not audited by one of the Big Four. This interaction measures the simultaneity between the set of accounting rules and the presence of one of the Big Four auditors. However, this finding cannot be considered conclusive within a $5 \%$ confidence interval.

Additionally, our findings indicate that larger firms are less likely to manage their earnings through discretionary accruals.

Contrary to previous findings (Rodríguez-Pérez \&Van Hemmen, 2010; Nardi et al., 2009), our results indicate that more leveraged firms manage earnings less. This result suggests that, unlike observed in the previous findings that higher indebtedness acts as an 
incentive to manipulate results, when the debt level grows, managers become more hesitant to engage in earnings management, perhaps due to greater pressure from creditors and more intense scrutiny of the financial ratios presented.

The process of IFRS convergence in Brazil is still recent, so this study was limited to a very short period under these standards. Considering this limitation, we suggest further research to analyze earnings management in Brazil over a longer period since the full implementation of IFRS in comparison with the prior period, to detect possible changes in the pattern of earnings management by means of discretionary accruals.

\section{REFERENCES}

AHN, S.; CHOI, W. The role of bank monitoring in corporate governance: evidence from borrowers' earnings management behavior. Journal of Banking \& Finance, v. 33, n. 2, p. 425-434, 2009.

ALMEIDA, J. E. F, et al. Earnings management. Contabilidade e Organizações, v. 3, n. 6, p. $81,2009$.

ALMEIDA, J. E. F.; ALMEIDA, J. C. G. de. Auditoria e earnings management: estudo empírico nas empresas abertas auditadas pelas big four e demais firmas de auditoria. Revista Contabilidade \& Finanças, v. 20, n. 50, p. 62-74, 2009.

ALVES, V. O.; LEMES, S. Nível de convergência dos princípios brasileiros e norteamericanos as normas do IASB: uma contribuição para a adoção das IFRS por empresas brasileiras. Revista Contabilidade \& Finanças, v. 22, n. 56, p. 155-173, 2011.

AUBERT, F.; GRUDNITSKI, G. Analysts' estimates: what they could be telling us about the impact of IFRS on earnings manipulation in Europe. Review of Accounting and Finance, v. 11, n. 1, p. 53-72, 2012.

AYERS, B. C.; RAMALINGEGOWDA, S.; YEUNG, P. E. Hometown advantage: the effects of monitoring institution location on financial reporting discretion. Journal of Accounting \& Economics, v. 52, v. 1, p. 41-61, 2011.

BARBOSA NETO, J. E.; DIAS, W. O.; PINHEIRO, L. E. T. Impacto da convergência para as IFRS na análise financeira: um estudo em empresas brasileiras de capital aberto.

Contabilidade Vista \& Revista, v. 20, n. 4, p. 131-147, 2009.

BARTH, M. E. et al. Are IFRS-based and US GAAP-based accounting amounts comparable? Journal of Accounting \& Economics, v. 54, n. 1, p. 68-93, 2012.

BAXTER, P.; COTTER, J. Audit committees and earnings quality. Accounting \& Finance, v. 49, n. 2, p. 267-290, 2009.

BONA-SÁNCHEZ, C.; PÉREZ-ALEMÁN, J.; SANTANA-MARTÍN, D. J. Defence measures and earnings management in an owner dominant context. Journal of Business Finance \& Accounting, v. 38, n. 7-8, p. 765-793, 2011. 
CHAN, K. et al. Share repurchases as a potential tool to mislead investors. Journal of Corporate Finance, v. 16, n. 2, p. 137-158, 2010.

CHEN, A.; KAO, L.; TSAO, M. To improve investors' valuation of accounting earnings in emerging markets: evidence from Taiwan. Canadian Journal of Administrative, v. 27, n. 4, p. 376-390, 2010.

CHEN, J.; LIAO, W. M.; LU, C. The effects of public venture capital investments on corporate governance: evidence from IPO firms in emerging markets. ABACUS, v. 48, n. 1, p. 86-103, 2012.

CHENG, P.; AERTS, W.; JORISSEN, A. Earnings management, asset restructuring, and the threat of exchange delisting in an earnings-based regulatory regime. Corporate Governance: an International Review, v. 18, n. 5, p. 438-456, 2010.

CHI, J.; GRUPTA, M. Overvaluation and earnings management. Journal of Banking \& Finance, v. 33, n. 9, p. 1652-1663, 2009.

CHOI, T. H.; PAE, J. Business ethics and financial reporting quality: evidence from Korea. Journal of Business Ethics, v. 103, n. 3, p. 403-427, 2011.

CHRISTIE, A. A.; ZIMMERMAN, J. L. Efficient and opportunistic choice of accounting procedures: corporate control contests. The Accounting Review, v. 69, n. 4, p. 539-567, 1994.

CHUNG, H.; SHEU, H.; WANG, J. Do firms' earnings management practices affect their equity liquidity? Finance Research Letters, v. 6, n. 3, p. 152-158, 2009.

COELHO, A. C.; LOPES, A. B. Avaliação da prática de gerenciamento de resultados na apuração de lucro por companhias abertas brasileiras conforme seu grau de alavancagem financeira. Revista de Administração Contemporânea, v. 11, n. 2, p. 121-144, 2007.

COHEN, D. A.; ZAROWIN, P. Accrual-based and real earnings management activities around seasoned equity offerings. Journal of Accounting \& Economics, v. 50, n. 1, p. 2-19, 2010.

CUPERTINO, C. M.; MARTINEZ, A. L. Qualidade da auditoria e earnings management: risk assessment através do nível dos accruals discricionários. Vista \& Revista, v. 19, n. 3, p. 69-93, 2008.

DEANGELO, L. E. Accounting numbers as market valuation substitutes: a study of management buyouts of public stockholders. The Accounting Review, v. 61, n. 3, p. 406420, 1986.

DECHOW, P. M.; SLOAN, R. G.; SWEENEY, A. P. Detecting earnings management. The Accounting Review, v. 70, n. 2, p. 193-225, 1995.

DEGEORGE, F.; PATEL, J.; ZECKHAUSER, R. Earnings management to exceed thresholds. Journal of Business, v. 72, n. 1, p. 1-33, 1999. 
ETTREDGE, M. et al. How do restatements begin? Evidence of earnings management preceding restated financial reports. Journal of Business Finance \& Accounting, v. 37, n. 34, p.332-355, 2010.

FERNANDES, P. F. M. O impacto da entrada em vigor das IFRS na gestão de resultados: a experiência Ibérica. 2007. 146 f. Dissertação (Mestrado em Ciências Empresariais) - Faculdade de Economia, Universidade do Porto, 2011.

FORMIGONI, H.; ANTUNES, M. T. P.; PAULO, E. Diferença entre o lucro contábil e lucro tributável: uma análise sobre o gerenciamento de resultados contábeis e gerenciamento tributário nas companhias abertas brasileiras. Brazilian Business Review, v. 6, n. 1, p. 44-61, 2009.

GARGOURI, R. M.; SHABOU, R.; FRANCOEUR, C. The relationship between corporate social performance and earnings management. Canadian Journal of Administrative Sciences, v. 27, n. 4, p. 320-334, 2010.

GHOSH, A.; MARRA, A.; MOON, D. Corporate boards, audit committees, and earnings management: pre- and post-SOX evidence. Journal of Business Finance \& Accounting, v. 37, n. 9, p. 1145-1176, 2010.

GUJARATI, D. N.; PORTER, D. C. Econometria básica. 5. ed. New York: McGraw-Hill, 2008.

GUTHRIE, K.; SOKOLOWSKY, J. Large shareholders and the pressure to manage earnings. Journal of Corporate Finance, v. 16, n. 3, p. 302-319, 2010.

HADANI, M.; GORANOVA, M.; KHAN, R. Institutional investors, shareholder activism, and earnings management. Journal of Business Research, v. 64, n. 12, p. 1352-1360, 2011.

HAZARIKA, S.; KARPOFF, J.; NAHATA, R. Internal corporate governance, CEO turnover, and earnings management. Journal of Financial Economics, v. 104, n. 1, p. 44-46, 2012.

HEALY, P. M. The impact of bonus schemes on accounting choices. Journal of Accounting and Economics, v. 7, n. 1-3, p. 85-107, 1985.

HUTTON, A.; MARCUS, A. J.; TEHRANIAN, H. Opaque financial reports, R 2, and crash risk. Journal of Financial Economics, v. 94, n. 1, p. 67-86, 2009.

IBRAHIM, S. S. The usefulness of measures of consistency of discretionary components of accruals in the detection of earnings management. Journal of Business Finance \& Accounting, v. 36, n. 9-10, p. 1087-1116, 2009.

IASCF - International Accounting Standards Committee Foundation. International Financial Reporting Standards - IFRS. Londres, 2010.

IATRIDIS, G. Audit quality in common-law and code-law emerging markets: evidence on earnings conservatism, agency costs and cost of equity. Emerging Markets Review, v.13, n. 2, p. 101-117, 2012. 
JAGGI, B.; LEUNG, S.; GUL, F. Family control, board independence and earnings management: evidence based on Hong Kong firms. Journal of Accounting and Public Policy, v. 28, n. 4, p. 281-300, 2009.

JEANJEAN, T.; STOLOWY, H. Do accounting standards matter? An exploratory analysis of earnings management before and after IFRS adoption. Journal of Accounting and Public Policy, v. 27, n. 6, p. 480-494, 2008.

JENSEN, M. C.; MECKLING, W. H. Theory of the firm: managerial behavior, agency costs and ownership structure. Journal of Financial Economics, v. 3, n. 4, p. 305-360, 1976.

JIANG, J.; PETRONI, K. R.; WANG, I. Y. CFOs and CEOs: who have the most influence on earnings management? Journal of Financial Economics, v. 96, n. 3, p. 513-526, 2010.

JONES, J. J. Earnings management during import relief investigations. Journal of Accounting Research, v. 29, n. 2, p. 193-228, 1991.

JORION, P.; SHI, C.; ZHANG, S. Tightening credit standards: the role of accounting quality. Review of Accounting Studies, v. 14, n. 1, p. 123-160, 2009.

JOUBER, H.; FAKHFAKH, H. Earnings management and board oversight: an international comparison. Managerial Auditing Journal, v. 27, n. 1, p. 66-86, 2012.

KANG, W. S.; KILGORE, A.; WRIGHT, S. The effectiveness of audit committees for lowand mid-cap firms. Managerial Auditing Journal, v. 26, n. 7, p. 623-650, 2011.

KANG, S.; SIVARAMAKRISHNAN, K. Issues in testing earnings management and an instrumental variable approach. Journal of Accounting Research, v. 33, n. 2, p. 353-367, 1995.

KIM, J.; YI, C. H. Does auditor designation by the regulatory authority improve audit quality? Evidence from Korea. Journal of Accounting and Public Policy, v. 28, n. 3, p. 207230, 2009.

KOTHARI, S. P.; LEONE, A. J.; WASLEY, C. E. Performance matched discretionary accrual measures. Journal of Accounting and Economics, v. 39, n. 1, p. 163-197, 2005.

LABELLE, R.; GARGOURI, R. M.; FRANCOEUR, C. Ethics, diversity management, and financial reporting quality. Journal of Business Ethics. v. 93, n. 2, p. 335-353, 2010.

LAMBERT, R.; LEUZ, C.; VERRECCHIA, R. E. Accounting information, disclosure, and the cost of capital. Social Science Research Network, mar. 2006. Disponível em: <http://papers.ssrn.com/sol3/papers.cfm?abstract id=823504>. Acesso em: 11 ago. 2011

LEE, G.; MASULIS, R. W. Do more reputable financial institutions reduce earnings management by IPO issuers? Journal of Corporate Finance, v. 17, n. 4, p. 982-1000, 2011.

LEUZ, C.; NANDA, D.; WYSOCKI, P. D. Earnings management and investor protection: an international comparison. Journal of Financial Economics, v. 69, n. 3, p. 505-527, 2003. 
LEVENTIS, S.; DIMITROPOULOS, P. E.; ANANDARAJAN, A. Loan loss provisions, earnings management and capital management under IFRS: the case of EU Commercial Banks. Journal of Financial Services Research, v. 40, n. 1, p. 103-122, 2011.

MCINNIS, J.; COLLINS, D. W. The effect of cash flow forecasts on accrual quality and benchmark beating. Journal of Accounting \& Economics, v. 51, n. 3, p. 219-239, 2011.

MARTINEZ, A. L. "Gerenciamento" dos resultados contábeis: estudo empírico das companhias abertas brasileiras. 2001. 162 f. Tese (Doutorado em Ciências Contábeis) Faculdade de Economia, Administração e Contabilidade, Universidade de São Paulo, 2001.

MARTINEZ, A. L. Detectando earnings management no Brasil: estimando os accruals discricionários. Contabilidade \& Finanças, v. 19, n. 46, p. 7-17, 2008.

MARTINEZ, A. L. Novo mercado, auditoria e o gerenciamento de resultados por escolhas contábeis e por decisões operacionais no Brasil. Fundação Instituto Capixaba de Pesquisas em Contabilidade, Economia e Finanças, 2009.

MARTINEZ, A. L. The role of analysts as gatekeepers: enhancing transparency and curbing earnings management in Brazil. Revista de Administração Contemporânea, v. 15, n. 4, p. 712-719, 2011.

MARTINEZ, A. L.; REIS, G. M. R. Rodízio das firmas de auditoria e o gerenciamento de resultados no Brasil. Revista de Contabilidade e Organizações, v. 4, n. 10, p. 48-64, 2010.

MARTINS, O. S.; BRASIL, A. M. S. A contabilidade internacional e a convergência às normas internacionais de contabilidade do IASB. QUALIT@S Revista Eletrônica, v. 7, n. 2, 2008. 14 p.

MARTINS, O. S.; PAULO, E. Reflexo da adoção das IFRS na análise de desempenho das companhias de capital aberto no Brasil. Revista de Contabilidade e Organizações, v. 4, n. 9, p. $30-54,2010$.

MATSUMOTO, A. S.; PARREIRA, E. M. Uma pesquisa sobre o gerenciamento de resultados contábeis: causas e consequências. Contabilidade, Gestão e Governança, v. 10, n. 1, p. 141-157, 2007.

NARDI, P. C. C.; NAKAO, S. H. Gerenciamento de resultados e a relação com o custo da dívida das empresas brasileiras abertas. Contabilidade \& Finanças, v. 20, n. 51, p. 77-101, 2009.

NARDI, P. C. C. et al. A relação entre gerenciamento de resultados contábeis e o custo de capital das companhias abertas brasileiras. Universo Contábil, v. 5, n. 4, p. 6-26, 2009.

NGUYEN, V. T.; XU, L. The impact of dual class structure on earnings management activities. Journal of Business Finance \& Accounting, v. 37, n. 3-4, p. 456-485, 2010.

NISKANEN, J. et al. Auditor gender and corporate earnings management behavior in private finnish firms. Managerial Auditing Journal, v. 26, n. 9, p. 778-793, 2011.

PAULO, E.; LEME, S. Gerenciamento de resultados contábeis e o anúncio dos resultados contábeis pelas companhias abertas brasileiras. Universo Contábil, v. 5, n. 4, p. 27-43, 2009. 
PAULO, E.; MARTINS, E.; CORRAR, L. J. Detecção do gerenciamento de resultados pela análise do diferimento tributário. Revista de Administração de Empresas, v. 47, n. 1, p. 46$59,2007$.

PRICE, R.; ROMÁN, F.; ROUNTREE, B. The impact of governance reform on performance and transparency. Journal of Financial Economics, v. 99, n. 1, p. 76-96, 2011.

RAYBURN, J. The association of operating cash flow and accruals with security returns. Journal of Accounting Research, v. 24, Studies on Alternative Measures of Accounting Income (1986), p. 112-133, 1986.

REZENDE, G. P.; NAKAO, S. H. Gerenciamento de resultados e a relação com o lucro tributável das empresas brasileiras de capital aberto. Universo Contábil, v. 8, n. 1, p. 6-21, 2012.

RODRÍGUEZ-PÉREZ, G.; VAN HEMMEN, S. Debt, diversification and earnings management. Journal of Accounting and Public Policy, v. 29, n. 2, p. 138-159, 2010.

SILVA, J. O.; BEZERRA, F. A. Análise do gerenciamento de resultados e o rodízio de firmas de auditoria nas empresas de capital aberto. Revista Brasileira de Gestão de Negócios, v. 12, n. 36, p. 304-321, 2010.

SHELTON, S.W. et al, Assessing the impact of reporting incentives on firm restatements in foreign and U.S. markets. Advances in Accounting, Incorporating Advances in International Accounting, v. 27, n. 1, p. 187-192, 2011.

SUN, J.; LIU, G.; LAN, G. Does female directorship on independent audit committees constrain earnings management? Journal of Business Ethics, v. 99, n. 3, p. 369-382, 2011.

TSIPOURIDOU, M.; SPATHIS, C. Earnings management and the role of auditors in an unusual IFRS context: the case of Greece. Journal of International Accounting, Auditing and Taxation, v. 21, n. 1, p. 62-78, 2012.

UNCTAD- United Nations Conference on Trade and Development. Global Investment Trends Monitor. Special Edition, 25 mar. 2013. Disponível em: $<$ http://unctad.org/en/PublicationsLibrary/webdiaeia2013d6 en.pdf $>$. Acesso em: 10 ago. 2013.

VASCONCELOS, C. et al. A influência da cobertura das empresas de rating sobre o gerenciamento de resultados das companhias abertas brasileiras. Revista de Contabilidade e Organizações, v. 2, n. 3, p. 37-52, 2008.

WANG, Y.; CAMPBELL, M. Corporate governance, earnings management, and IFRS: empirical evidence from Chinese domestically listed companies. Advances in Accounting, Incorporating Advances in International Accounting, v. 28, n. 1, p. 189-192, 2012.

WANG, L.; YUNG, K. Do state enterprises manage earnings more than privately owned firms? The case of China. Journal of Business Finance \& Accounting, v. 38, n. 7-8, p. 794$812,2011$.

WATTS, R.; ZIMMERMAN, J. Positive accounting theory. New Jersey: Prentice-Hall, 1986. 
WILSON, M.; WANG, L. W. Earnings management following chief executive officer changes: the effect of contemporaneous chairperson and chief financial officer appointments. Accounting \& Finance, v. 50, n. 2, p. 447-480, 2010.

WILSON, M.; WU, Y. Do publicly signalled earnings management incentives affect analyst forecast accuracy? Abacus, v. 47, n. 3, p. 315-342, 2011.

ZÉGHAL, D.; CHTOUROU, S.; SELLAMI, Y. M. An analysis of the effect of mandatory adoption of IAS/IFRS on earnings management. Journal of International Accounting, Auditing and Taxation, v. 20, n. 2, p. 61-72, 2011.

ZONATTO, V. C. S. et al. Fatores determinantes para a adoção de padrões internacionais de contabilidade no Brasil: uma investigação em empresas públicas e privadas do setor de energia elétrica. Revista de Contabilidade e Organizações, v. 5, n. 12, p. 26-47, 2011.

\footnotetext{
${ }^{\mathrm{i}}$ The author is grateful for the financial support provided by CAPES through scholarship doctoral internship at the University of Salamanca, as part of Project CAPES/DGY 270/12 led by PhD Maria Thereza Pompa Antunes, whom I thank for their support and knowledge imparted. I thank PhD Henrique Formigoni and PhD Isabel Gallego Alvarez by shared knowledge during the preparation of this article.
} 